\title{
The Cost of Toxic Leadership: What the Board Didn't See.
}

\author{
Helen MacLennan \\ Saint Leo University
}

Sherry was held in high regard by the board of directors. She successfully managed a large and highly profitable real estate portfolio in the Southeast, driving revenue up and costs down. However, her toxic leadership style drove many employees away; some of which went on to lodge complaints with OSHA and the EEOC. What the board didn't see was how much her toxic leadership style was costing the organization.

\section{INTRODUCTION}

Sherry was the regional vice president of a large national real estate investment and management organization. She managed the company's Southeast U.S. portfolio, which was highly profitable. The board of directors, located on the West coast, viewed her as extremely successful; her portfolio consistently outperformed others around the country. Charlie Pearson, Michael Walters and the other employees saw a different side of Sherry. They saw consistent and pervasive mistreatment that permeated the entire region.

\section{THE ORGANIZATION}

A large national real estate organization headquartered on the West coast. The company owned and managed millions of square feet of industrial income-producing properties and continued to expand, acquiring more properties every year. They were highly profitable and focused on both growth and revenue generation.

Sherry was responsible for the operations in the Southeast region, which was headquartered and focused in the state of Florida. The Southeast portfolio was comprised of more than 3 million square feet of industrial space and produced a sizeable profit.

\section{THE EMPLOYEES}

The Florida offices were comprised of 12 employees including a senior property manager, two property managers, two assistant property managers, a leasing manager, two assistant leasing managers, an accounting clerk, a contract management clerk, a receptionist, and Sherry's administrative assistant.

Charlie Pearson was a property manager with many years of experience and held an MBA. He joined the organization in 2012 with the hope of making the job a long-term career. Although he was one of the 
company's younger employees, he was personable, knowledgeable and had developed great relationships with many of the tenants. Little did he know when he started the job, he'd someday be ushered out of the office with his belongings by a security guard after telling Sherry that he would not permit her to speak to him with utter disrespect.

Michael Walters was a hardworking family man with 4 children and had been with the organization for nearly eight years. He was an accounting clerk with a vast knowledge of the inner-workings of the organization and frequently assisted in other areas. Michael wanted to advance in the company and was told that he would need to have a college degree in order to do so. Consequently, Michael began taking evening business courses. The stress of family, work, school, and the mistreatment he suffered at work were taking their toll on him. He struggled to deal with the daily degradation that was dished out by Sherry, but knew he had to support his family so his options were limited. Michael finally landed another job and was able to leave, but Sherry did not allow him to work out his 2-week notice.

\section{THE LEADER}

The real estate market was recovering in Florida and Sherry successfully managed a highly profitable real estate portfolio with the help of her staff. The board of directors praised her and she was known as a "tough as nails" leader. What the board didn't see was the pervasive mistreatment of the employees who worked for her and how her toxic leadership style resulted in a negative impact on both her employees and the bottom line.

Sherry maintained tight control over her staff. In fact, every staff member in the southeast was required to e-mail her a daily accounting of how they spent their day and what was accomplished. Many of the employees were salaried and worked until well after dark, but there was no excuse. Those who didn't produce the daily e-mail received a stern warning.

The weekly staff meeting was the time to discuss new tenants, projects, income and expenses. It was also a time that every employee dreaded. Those who couldn't answer the questions fired off by Sherry were belittled and ridiculed in front of their coworkers.

It was a frequent occurrence to hear Sherry talking about her employees in the office and encouraging others to join in. When referring to a new employee who had asked a question, Sherry said "she's old and probably has Alzheimer's." It got a chuckle from some while others found it reprehensible.

On the morning of a weekly staff meeting, the receptionist delivered coffee to the room. Once she left, V remarked "she's worthless." However, the rude remarks were not always veiled. Those employees who were not in Sherry's inner circle were direct targets for rude, disrespectful, and unrelenting mistreatment.

\section{THE SITUATION}

Within a twelve-month period, Sherry replaced 7 of twelve staff members who had either quit or been fired. Several of them walked out with no notice. The home office on the west coast was beginning to wonder what was happening. These are just 2 of the stories:

Charlie Pearson had been the only employee to voice his disapproval of Sherry's rude comments. In fact, when confronted by Sherry in front of his coworkers, Charlie remarked "I am a professional and you will not talk to me that way." It marked the beginning of the end for Charlie. Sherry immediately contacted human resources and Charlie was written up for insubordination. He knew he was a good worker and wasn't going to stand by and let her destroy his reputation. Charlie made his own call to human resources. They promised to send someone down who would interview him along with the rest of the employees.

Michael Walters needed his job so he didn't want to make waves. He suffered in silence while he waited for another job offer. Michael had indicated to a coworker that he wasn't happy in his current position and Sherry caught wind of it. She knew that a representative from human resources was planning a trip. As a result, Sherry called him into her office and told him I am going to help you find another job. 
Michael wasn't sure that he wanted her help. "I know how she is. I don't want her to cook up a bunch of stories about me to a future employer."

A representative from human resources was sent into the office. By then, Charlie was on paid leave, but was able to tell his story by phone. "I told her everything that went on, but she asked if I might be exaggerating. It was like she had already made up her mind and didn't want to hear my side of the story." Charlie thought she would be more receptive, but it appeared that she was only there for damage control. "She wasn't there to help him; she just wanted me to keep quiet."

It was Michael's turn for an interview. He was torn over whether to tell the truth or just keep quiet since he was leaving anyway. In the end, he decided that it probably wouldn't make much difference if he told the truth and it may end up costing him his job before he found a replacement. Michael said nothing about the mistreatment he had suffered at the hands of Sherry. "I didn't want to cause trouble."

The remainder of the employees were interviewed, all of whom wanted to keep their jobs and like Michael, didn't want to cause trouble. As a result, the human resources representative went home in support of Sherry's contention that she was tough, but fair and that those employees who left had done so because they were somehow inferior workers. She had convinced human resources, and ultimately the board, that she was doing the right thing.

\section{THE COSTS}

As we know, there are costs associated with replacing an employee. The cost of attracting, interviewing, loss of productivity and training must be considered. Based on a study that reviewed 31 case studies, Lucas (2012) estimates the cost of replacement at approximately $20 \%$ of an employee's annual income. However, the estimates are modest as Human Resources, Inc. estimates that replacement costs can be $30-50 \%$ of the annual salary of entry-level employees, $150 \%$ for mid-level employees, and up to $400 \%$ for specialized, high-level employees (HRI, 2013).

There are also hidden costs that are difficult to quantify. Lipman (2013) provided that unhappy employees are not engaged and are cost the organization in productivity. He estimates the loss at approximately $35 \%$ of payroll. He also indicated that they are also much more likely to steal from the company, call in sick, and negatively influence their coworkers. Both Charlie and Michael indicated that they had each taken at least 2 additional sick days in a 12-month period due to stress.

Table 1 provides an estimate of the annual salaries for the 7 employees that were replaced and the estimated costs of their lack of productivity along with the cost of replacement. The table does not include a loss of productivity estimate for the employees who remained behind, but were likely unhappy. The very conservative estimate of $\$ 197,976$ represents the annual cost of Sherry's toxic leadership style. The board might be interested in seeing these numbers. 
TABLE 1

ESTIMATED ANNUAL COSTS

\begin{tabular}{|l|l|l|l|l|l|l|l|l|}
\hline & 1 & 2 & 3 & 4 & 5 & 6 & 7 & Total \\
\hline $\begin{array}{l}\text { Estimated Annual } \\
\text { Salary }\end{array}$ & $\$ 60,000$ & $\$ 40,000$ & $\$ 65,000$ & $\$ 60,000$ & $\$ 50,000$ & $\$ 45,000$ & $\$ 35,000$ & $\$ 355,000$ \\
\hline $\begin{array}{l}\text { Est. Cost of } \\
\text { Replacement }\end{array}$ & $\$ 12,000$ & $\$ 8,000$ & $\$ 13,000$ & $\$ 12,000$ & $\$ 10,000$ & $\$ 9,000$ & $\$ 7,000$ & $\$ 71,000$ \\
\hline $\begin{array}{l}\text { Est. Cost of Loss } \\
\text { of Productivity }\end{array}$ & $\$ 21,000$ & $\$ 14,000$ & $\$ 22,750$ & $\$ 21,000$ & $\$ 17,500$ & $\$ 15,750$ & $\$ 12,250$ & $\$ 124,250$ \\
\hline $\begin{array}{l}\text { Est. Cost of 2 } \\
\text { Extra Sick Days }\end{array}$ & $\$ 460$ & $\$ 307$ & $\$ 500$ & $\$ 460$ & $\$ 384$ & $\$ 346$ & $\$ 269$ & $\$ 2,726$ \\
\hline & & & & & & & & \\
\hline $\begin{array}{l}\text { Estimated Total } \\
\text { Cost }\end{array}$ & $\$ 33,460$ & $\$ 22,307$ & $\$ 36,250$ & $\$ 33,460$ & $\$ 27,884$ & $\$ 25,096$ & $\$ 19,519$ & $\$ 197,976$ \\
\hline
\end{tabular}

\section{ENDNOTES}

1. Due to the nature of this case, the name of the organization is intentionally omitted and the names of the employees have been changed. The intent of this case is to provide concepts for discussion related to leadership, organizational culture and human resource management to undergraduate students.

\section{REFERENCES}

HRI (2013). The hidden deadly costs of employee turnover. HR Matters. Retrieved from http://www.hrionline.com/blog/the-hidden-deadly-costs-of-employee-turnover

Lipman, V. (2013). Surprising, disturbing facts from the mother of all employment surveys. Forbes.

Retrieved from http://www.forbes.com/sites/victorlipman/2013/09/23/surprising-disturbing-factsfrom-the-mother-of-all-employee-engagement-surveys/

Lucas, S. (2012). How much does it cost companies to lose employees? CBS News Moneywatch.

Retrieved from http://www.cbsnews.com/news/how-much-does-it-cost-companies-to-loseemployees/ 